\title{
PELAKSANAAN PEMBERIAN PELATIHAN OPTIMALISASI MEDIA PEMBELAJARAN BERBASIS MEDIA VISUAL DI SMPN 12 TANGERANG SELATAN BANTEN
}

\author{
Budi Haryono, Rr. Renny Anggraini, Amirudin, Ida Nurlina, Dede Hendra \\ Universitas Pamulang \\ dosen00980@unpam.ac.id
}

\begin{abstract}
This PKM taking the object teachers in SMPN 12 Tangsel for the implementation. During this pandemic covid 19, teachers have a problem to teach learning materials to their students because of government regulations that states to stay at home and doing all the task from home. Ministry of Education suggests online learning. This matter gives resistance to teachers and students because most of them don't have communication devices to support this online learning. Regarding that problem, the PKM program is expected to be given motivation and training by video as a visual media that can be accessed by the internet and WhatsApp. Implementation of PKM program doing by Dosen Unpam as a committee. Hopefully, this PKM program can be helping teachers in SMPN 12 Tangsel to passing this pandemic.
\end{abstract}

\section{Keywords: Training, Visual Media}

\begin{abstract}
ABSTRAK
Pada PKM yang dilakukan dengan mengambil objek guru-guru SMPN 12 Tangsel. Selama adanya pandemi ini para pendidik di lingkungan SMPN 12 Tangsel masih mengalami kendala dalam pengemasan materi pembelajaran daring di era Covid-19, dikarenakan peraturan pemerintah yang menyatakan untuk tinggal dirumah dan melakukan pekerjaan dari rumah. Kementerian Pendidikan dan Kebudayaan menyarankan untuk memberikan pembelajaran secara daring (online). Tetapi hal ini menimbulkan hambatan baru di karenakan masih banyak kendala untuk dilakukan oleh pendidik dan peserta didik yang tidak memiliki alat komunikasi yang bisa mendukung pembelajaran tersebut. Melihat dari hal tersebut maka kami panitia penyelenggara PKM berinisiatif untuk memberikan bantuan motivasi dan pelatihan singkat tentang pemanfaatan media pembelajaran berbasis video sebagai salah satu media visual yang tidak hanya dapat diakses melalui jaringan internet, tetapi juga dapat dikirimkan melalui Whatsapp dalam bentuk file materi maupun penugasan. Semoga PKM ini dapat membantu guru di SMPN 12 Tangsel
\end{abstract}

Kata Kunci : Pelatihan, Media Visual 


\section{A. PENDAHULUAN}

Dalam rangka kegiatan Pengabdian Kepada Masyarakat kami melakukan kerjasama dengan SMPN 12 Tangerang Selatan, Banten. Berdasarkan Peraturan Pemerintah Republik Indonesia Nomor 21 tahun 2020 Tentang Pembatasan Sosial Berskala Besar yaitu Percepatan Penanganan Corona Virus Disease 2019 (Covid-19) dan Pemerintah Gubenur No. 25 tahun 2020 tentang Pemberlakuan PSBB di Kabupaten Tangerang, Kota Tangerang dan Kota Tangerang Selatan ini dikarenakan adanya Pandemi Covid-19 sehingga warga dilarang untuk beraktivitas keluar rumah. Hal ini dilakukan untuk mencegah penyebaran Covid-19 di daerah sekitarnya. Khususnya Jawa Barat merupakan provinsi yang semakin naik pada kasus pandemi ini, sehingga dikeluarkannya Peraturan Daerah mengenai Pembatasan Sosial Berskala Besar yaitu Peraturan Walikota No. 13 Tahun 2020 yang sama tentang membatasi kegiatan tertentu dan pergerakan orang dan/atau barang dalam rangka menekan penyebaran Covid-19.

Hal ini sangat berdampak pada masyarakat yang bertugas sebagai pendidik sekolah menengah dan para peserta didik dilingkungan kota Tangerang Selatan. Dari hasil survey dan wawancara melalui SMPN 12 Tangsel bahwa permasalahan yang ada sekarang ini dan masih berlanjut salah satunya adalah para pendidik di lingkungan SMPN 12 Tangsel masih mengalami kendala dalam pengemasan materi pembelajaran daring di era Covid-19, dikarenakan terbatasnya aktivitas keluar rumah untuk menunaikan tugasnya secara langsung pada peserta didik sebagai pendidik. Kementerian Pendidikan dan Kebudayaan menyarankan untuk memberikan pembelajaran secara daring (online), hal ini di karenakan masih banyak kendala untuk dilakukan oleh pendidik dan peserta didik yang tidak memiliki alat komunikasi yang bisa mendukung pembelajaran tersebut. Selain itu, mereka juga tidak memiliki kuota yang besar serta pengetahuan untuk melakukan zoom atau webex seperti yang dilakukan oleh sekolah-sekolah negeri atau swasta lainnya.

Solusi yang dibutuhkan terhadap Permasalahan Mitra yang merupakan pendidik dan peserta didik di SMPN 12 Tangsel adalah dengan memberikan alternative pembelajaran daring dengan metode asinkoronos (Asynchronous) yang banyak dan dapat digunakan secara gratis oleh banyak penyedia platform atau aplikasi maupun situs yang telah tersedia di internet. Dengan adanya pandemi Covid-19 para pendidik dan peserta didik merasa kesulitan melaksanakan tugas dan tanggungjawabnya dikarenakan tidak adanya izin untuk beraktivitas tatap muka langsung di kelas-kelas yang ada di sekolah. Oleh karena itu dosen Universitas Pamulang khususnya program studi manajemen bekerjasama dengan SMPN 12 Tangsel memberikan bantuan motivasi dan pelatihan singkat tentang pemanfaatan media pembelajaran berbasis video yang tidak hanya dapat diakses melalui jaringan internet, tetapi juga dapat dikirimkan melalui Whatsapp dalam bentuk file materi maupun penugasan

Selain itu, kegiatan ini membantu para pendidik untuk dapat melakukan kegiatan kemitraan melalui berbagai ilmu kepada para pendidik terutama yang tidak atau belum mendapatkan pengalaman tentang pemanfaatan media pembelajaran dalam bentuk video pembelajaran sederhana yang dapat dihasilkan dari slide presentasi. Pemerintah menyarankan untuk melakukan kegiatan belajar mengajar melalui online/daring sedangkan para pendidik maupun peserta didik yang telah memiliki alat komunikasi berupa smartphone masih terdendala dengan belum memadainya kuota yang digunakan.

Kami selaku dosen manajemen memiliki target dalam kegiatan ini untuk membantu kemitraan dengan SMPN 12 Tangsel melalui peningkatan kompetensi pembelajaran yang memanfaatkan media pembelajaran berbasis video yang dapat dihasilkan dari file presentasi, 
sehingga para pendidik bisa mengekspresikan materi pembelajarannnya yang sudah dikemas dalam bentuk video yang dapat diakses peserta didik dengan mudah dan tentunya yang paling penting adalah penggunaan kuota yang tidak terlalu besar karena tidak dilakukan secara sinkron atau secara tatap muka virtual baik melalui aplikasi zoom, webex, meet maupun aplikasi sinkronos lainnya yang tentu membutuhkan kuota yang cukup besar.

\section{B. METODE PELAKSANAAN KEGIATAN}

Tujuan pelaksanaan kegiatan PKM ini adalah untuk: (1) Memberikan pemahaman mengenai dampak positif maupun dampak negatif perkembangan teknologi kepada para pendidik di SMPN 12 Tangerang Selatan, (2) Memberikan pengetahuan mengenai manfaat dari perkembangan teknologi kepada para pendidik di SMPN 12 Tangerang Selatan, (3) Memberikan pengembangan dalam pemanfaatan kemajuan teknologi kepada para pendidik di SMPN 12 Tangerang Selatan.

Metode kegiatan yang digunakan adalah bekerjasama dengan guru di SMPN 12 Tangsel dan mencari bantuan apa yang dibutuhkan oleh para guru dalam menyampaikan materi pelajaran yang cukup rumit kepada para siswa siswinya. Kami selaku Dosen Manajemen memberikan masukan kepada mereka untuk membantu kemitraan SMPN 12 Tangerang Selatan meningkatkan kegiatan pembelajaran di lingungan sekolah, sehingga para pendidik dan peserta didik dapat melakukan pembelajaran dengan perangkat minimal yang dimiliki oleh para pendidik maupun peserta didik. Berikut ini adalah tahapan yang dilakukan dalam pemberian bantuan:

1. Tahap Persiapan

a. Survey awal

b. Pemantapan dan penentuan lokasi dan sasaran.

Setelah survey dilakukan maka ditentukan lokasi pelaksanaan dan sasaran penerima bantuan

2. Tahap Pelaksanaan Pengabdian Kepada Masyarakat

Setelah melakukan survey dan persiapan sarana dan prasarana maka pelaksanaan kegiatan dilaksanakan oleh pengusul beserta anggota dan beberapa mahasiswa. Kegiatan yang dilakukan adalah dengan mempresentasikan materi pembinaan data penyuluhan yang disampaikan oleh semua anggota pelaksanaan kegiatan Pengabdian Kepada Masvarakat.

3. Tahap Monitoring dan Evaluasi

Kegiatan ini dimaksudkan untuk membantu para pendidik di SMPN 12 Tangerang Selatan, Banten dalam menghadapi pandemic virus corona dan untuk sedikit meringankan beban yang mereka emban selama pandemi covid 19 ini berlangsung. Evaluasi juga bertujuan untuk memahami apakah bantuan pelatihan singkat yang diberikan dapat meningkatkan semangat dan kreativitas para pendidik dalam memberikan pengajaran kepada para peserta didik. Hal ini diharapkan mampu menjadi motivasi bagi para pendidik di SMPN 12 Tangerang Selatan, Banten

\section{HASIL DAN PEMBAHASAN}

Kegiatan pemberian pelatihan diberikan oleh dosen Universitas Pamulang yang bekerja sama dengan pendidik di SMPN 12 Tangerang Selatan, Propinsi Banten. Pelatihan singkat disampaikan kepada sekitar 35 pendidik di lingkungan SMPN 12 Tangsel. Selain itu panitia juga melakukan kegiatan pelatihan dalam bentuk motivasi bagi para pendidik yang mengalami kendala akibat pandemi covid 19. Kegiatan pelatihan dimulai dari pembukaan acara oleh Budi Haryono, S.Kom., M.Ak. Setelah itu dilanjutkan dengan pembacaan ayatayat suci Al Quran oleh Bapak Dede Hendra, S.E., M.M. Lalu Kepala Sekolah SMPN 12 
Tangsel yaitu Bapak Drs. Nofiardi juga turut memberikan kata sambutan untuk semua panitia dan peserta pelatihan. Antusiasme peserta pelatihan terlihat selama acara berlangsung. Rasa bahagia terpancar dari raut wajah mereka karena mereka merasakan kepedulian yang tinggi akan nasib mereka akan sulitnya penyampaian materi pelajaran melalui online learning.

Dalam kegiatan tersebut, panitia membantu proses pelatihan singkat pemanfaatan pembelajaran berbasis media visual ini kepada para peserta pelatihan. Protokol kesehatan juga diterapkan dan dipatuhi oleh semua panitia dan para peserta yang hadir serta panitia dari pihak sekolah yang turut membantu selama acara berlangsung. Para panitia dan peserta diwajibkan untuk menjaga jarak tempat duduk, memakai masker, dan mengatur komunikasi antara satu dengan yang lainnya guna mencegah penularan virus corona. Acara berakhir tepat waktu sehingga mengurangi resiko adanya perkumpulan massa.

Alhamdulillah kegiatan pelaksanaan pemberian pelatihan singkat kepada para pendidik di SMPN 12 Tangerang Selatan, Banten berlangsung tertib dan lancar tanpa adanya kendala. SMPN 12 Tangerang Selatan sebagai tempat pelaksanaan kegiatan ini memberikan apresiasi yang tinggi kepada dosen Universitas Pamulang pada upayanya untuk meringankan kendala yang dialami para pendidik di SMPN 12 Tangerang Selatan akibat adanya pandemi virus corona selama beberapa bulan belakangan ini

\section{KESIMPULAN DAN SARAN Kesimpulan}

Pelaksanaan kegiatan Pengabdian Kepada Masyarakat oleh Lembaga Penelitian dan Pengabdian Masyarakat (LPPM) Universitas Pamulang yang dilakukan oleh dosen-dosen program studi Manajemen telah berjalan dengan lancar dan mendapat sambutan hangat dari tempat pelaksanaan kegiatan ini yaitu Kepala Sekolah SMPN 12 Tangerang Selatan. Harapan kami dengan pengabdian ini dapat meringankan beban kendala dari para pendidik sebagai dampak dari pandemic covid 19. Dalam laporan kegiatan ini mungkin banyak kekurangan yang ada, untuk itu kami berharap masukan dan kritikan dalam rangka perbaikan untuk kegiatan-kegiatan pengabdian masyarakat di masa yang akan datang. Semoga kegiatan pengabdian masyarakat ini dapat bermanfaat bagi masyarakat sekitar lingkungan Universitas Pamulang dan lainnya

\section{Saran}

Berdasarkan uraian hasil pengabdian masyarakat yang telah dilaksanakan, maka kami memberikan saran:

1. Menanamkan rasa cinta kasih, saling peduli, dan tolong menolong dengan memberikan

2. terhadap sesama manusia tanpa memandang suku, ras, dan agama.

3. Menggalakan program - program bantuan lainnya yang menyasar pada golongan masyarakat yang kurang mampu

4. Bantuan yang diberikan bisa lebih bervariasi lagi sesuai kebutuhan kalangan masyarakat yang hendak diberikan bantuan

\section{DAFTAR PUSTAKA}

Anggara, D. S., Abdillah, C., Permana, P. S., Prasetyawan, E. (2020). Pendampingan pengembangan produk ilmiah Pendidikan bagi guru di Yayasan nurul hidayah, Bojongsari, Depok. Jurnal Abdi Laksana, 1(2), 218-222.

Ilmadi., Aden., Sastro, G., Rusdiana, Y., Isnurani (2020). Pelatihan Penggunaan Moodle untuk Mengoptimalkan Pembelajaran secara Online. Jurnal Abdidas, 1(6), 592-596. 
Lesmana, R., Sunardi, N., Tumanggor, M. (2020). Pelatihan Manajemen dalam Meningkatkan Motivasi Siswa dan Guru SDN 84 Rejang Lebong. Jurnal Abdi Masyarakat Humanis, 1(2), 105-112.

Yuwono, T., Rovita, A., Nani., Zulkarnain, I., Hindriani, R. (2020). Penguatan Sumber Daya Manusia (SDM) Guru di Yayasan Ini Media Kita Gunung Sindur Bogor. Jurnal Abdi Laksana, 1(3), 451-456. 